\title{
Selection of optimal places for constructions of renewable energy stations in Myanmar using analytic hierarchy process (AHP) method
}

\author{
Thu Yein Min, Michael Tyagunov, and He Haiyang \\ National Research University "Moscow Power Engineering Institute”, Moscow, Russia.
}

\begin{abstract}
The article discusses the formulation of the problem of choosing the optimal places for building renewable energy stations in Myanmar using the analytical hierarchical process (AHP) method. Today Myanmar is a developing country in Southeast Asia. Myanmar possesses a variety of energy resources, including renewable and non-renewable energy sources. Humans have especially used, and are now using, fossil fuels. After 2010, Myanmar began to focus heavily on renewable energy sources (RES). The Ministry of Electricity and Energy (MOEE) is the responsible ministry for the energy sector in Myanmar. MOEE is also responsible for the production, production and transportation of oil and gas. Myanmar has long been isolated from international markets, and funding sources have historically limited development and therefore pressure on its environment. Many of its resources remain relatively intact despite the lack of effective environmental regulations. However, as the country integrates into the world economy and its economic development are accelerating, resource degradation is growing rapidly. Deforestation of closed forests in recent years has been the fastest growing among large Southeast Asian countries, most of which are driven by plantation concessions and other large-scale projects. In order to reduce the use of fossil fuels and increase the use of renewable energy sources in Myanmar, it is necessary to investigate where and which RES are optimal depending on all situations.
\end{abstract}

\section{Introduction}

Myanmar is a state in the western part of the Indochina Peninsula of Asia. Until 1989, the country was officially called Burma. It is located between $9^{\circ} 32^{\prime}$ and $28^{\circ} 31^{\prime}$ degrees north latitude and between $92^{\circ} 10^{\prime}$ and $101^{\circ} 11^{\prime}$ east longitude. The area of the country is 678,500 $\mathrm{km} 2$. In the west, Myanmar borders with Bangladesh and India, in the north and northeast with China, in the east with Laos, in the southeast with Thailand. The total length of the border is $5876 \mathrm{~km}$, of which $2185 \mathrm{~km}$ are on the border with China, $1800 \mathrm{~km}$ - on the border with Thailand [1]. From the southwest, the country is washed by the waters of the Bay of Bengal, from the south - by the waters of the Andaman Sea. The length of the coastline is $2832 \mathrm{~km}$. Myanmar includes the Mewi (Myei) archipelago, located in the 
Andaman Sea. The length of the country from north to south is 2051 kilometers and 936 kilometers from west to east [2]. Two-thirds of Myanmar is located between the equator and the northern tropic; therefore, most of the country is dominated by a tropical and subtropical climate, formed under the influence of monsoons [3]. There are three seasons: rainy, lasting from late May to late October; cool - from late October to mid-February and hot - from mid-February to late May [4]. The average annual ambient temperature ranges from $22^{\circ} \mathrm{C}$ to $27^{\circ} \mathrm{C}$, however, in $70 \%$ of the country's territory in March and April, the temperature exceeds $40^{\circ} \mathrm{C}$ during the day, however, in some northern regions located in high mountains, the temperature drops to $0{ }^{\circ} \mathrm{C}$ in cool season [5]. 135 nationalities live in Myanmar. The country's population was over 60 million with an annual population growth of $0.8 \%$ in 2012 . More than $70 \%$ of the country's population lives in rural areas in more than 60,000 villages. Myanmar had a total primary energy supply (TPES) of 16.57 Mtoe (Million tons of oil equivalent) in 2013. Electricity consumption was 8.71 TWh. $65 \%$ of the primary energy supply consists of biomass energy, which is used almost exclusively $(97 \%)$ in the residential sector. Per capita energy consumption in Myanmar is one of the lowest in Southeast Asia due to low electrification and widespread poverty. An estimated $65 \%$ of the population is not connected to the national grid. However, energy consumption is growing rapidly, with a CAGR of 3.3\% from 2000 to 2007. Most of Myanmar's electricity $(74.7 \%)$ is generated by hydropower. The remainder is fossil fuels, of which gas is the main fuel (20.5\%), followed by coal and oil. In 2017, Myanmar's installed electrical capacity was around 5 gigawatts (GW). The country plans to achieve $100 \%$ electrification by 2030 . The country plans to produce $12 \%$ of all electricity from renewable sources by 2025 . The total installed capacity of Myanmar as of May 2020 is 6,034 MW: 3,262 MW of hydropower $(54 \%), 2,496 \mathrm{MW}$ of natural gas $(41 \%), 120 \mathrm{MW}$ of coal $(2 \%), 116 \mathrm{MW}$ of diesel $(2 \%)$. and $40 \mathrm{MW}$ solar energy $(1 \%)$. The cost of generating electricity was found to be 12 kyat per $\mathrm{kWh}$ for public hydroelectric power plants, 72 kyat per $\mathrm{kWh}$ for private hydropower plants, 150 to 190 kyat per kWh for natural gas power plants, and 195 kyat per kWh for solar power plants. Power plants. At the annual meeting of the Myanmar Oil and Gas Society on January 24, 2021, Minister mentioned that the country is moving to a new energy structure: hydropower - 40\%, solar energy - $14 \%$, domestic gas - $34 \%$ and LNG $11 \%$. This will bring the composition of renewable energy to $54 \%$ and the composition of clean fuel (natural gas) to $45 \%$ of the total installed capacity of 8,118 megawatts (MW). Myanmar's electrification rate is one of the lowest in Asia at 50\% in December 2019. Electrification is especially low in rural areas, which are mostly not connected to the grid. In these areas, wood and biomass are used as the main sources of energy. Myanmar has abundant energy resources, especially hydropower and natural gas. In 2013, Myanmar exported 8,561 thousand toe of natural gas and 144 thousand toe of oil. The country is one of the top five energy exporters in the region and is the second largest natural gas exporter in the Asia-Pacific region after Indonesia. According to the World Energy Council, gas reserves are estimated at 244 Mtoe. Oil and coal play a lesser role, reserves are estimated at 7 and 1 Mtoe, respectively [6].

In fig. 1. map of Myanmar presented. 


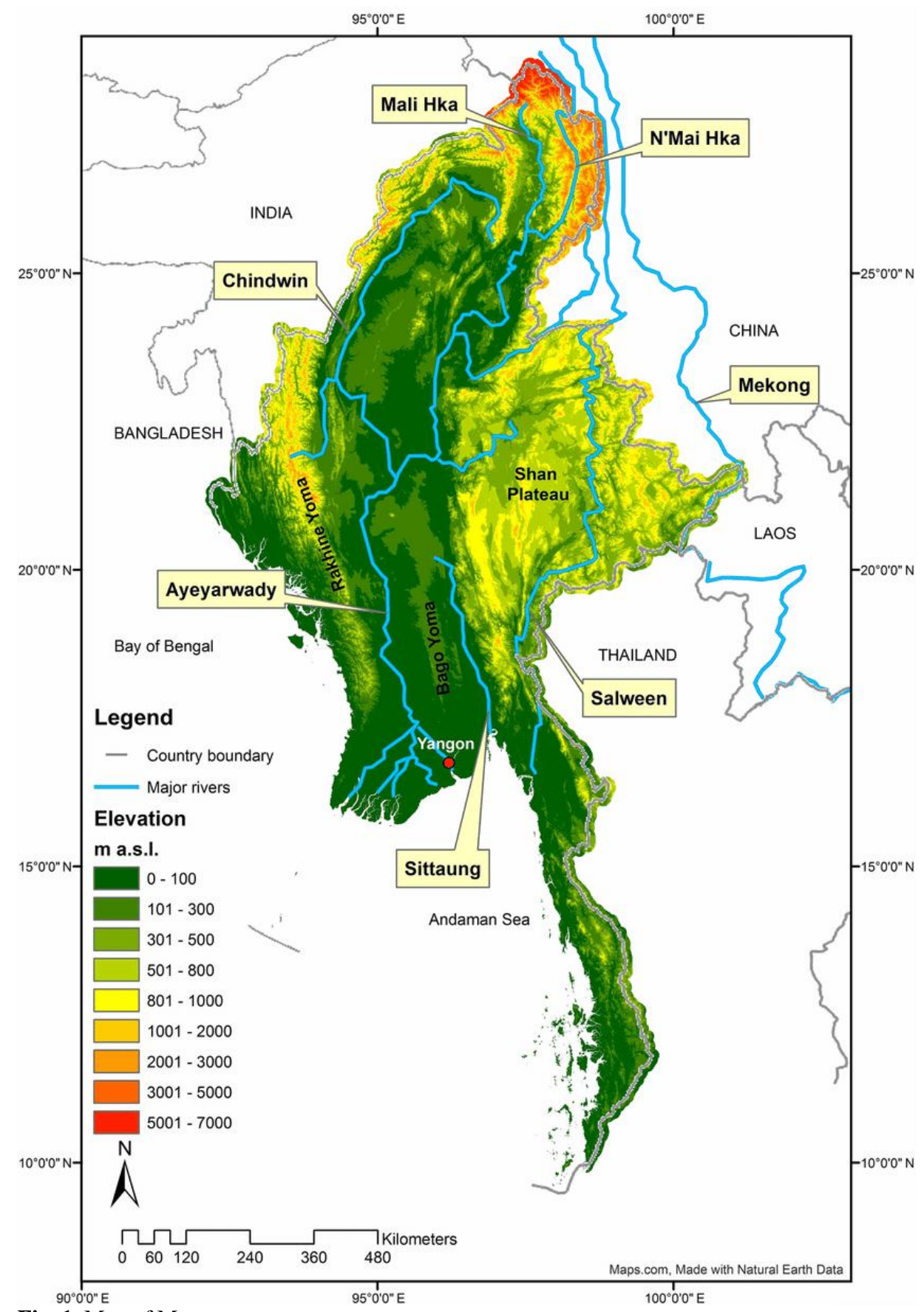

Fig. 1. Map of Myanmar.

\subsection{State of the country}

As of September 2014, out of 814 plants nationwide, the total generation capacity was 4,581 MW, of which 3,044 MW (66.46\%) came from hydropower. The high dependence on hydropower causes unstable supply as the reservoirs behind the dams shrink during the 
hot season. As of September 17, with $33 \%$ of the population having access to electricity, the peak load was 2,171 MW, the per capita consumption was 232 kilowatt-hours. Myanmar has presented a 15-year energy development plan to meet the growing demand for electricity, with plans to increase capacity from 4,581 MW to 29,000 MW by 2031. The Ministry of Electricity, expressed that the new plan involves the transition from hydropower to other sources of energy, including coal, natural gas, solar and wind energy. In 2031, Myanmar will have 41 power plants. [8] As of today, the Ministry of Electricity and Energy of Myanmar has expressed that a National Electricity Power Plan (NEPP) has already been established [9]. Buildings for electricity and the village that have already received electricity by November 2020 .

Table 1. Buildings for electricity and villages that have already received electricity before November 2020.

\begin{tabular}{|c|c|c|c|c|}
\hline No. & States and regions & $\begin{array}{c}\text { Constructions for } \\
\text { electricity }\end{array}$ & $\begin{array}{l}\text { the villages that } \\
\text { have already } \\
\text { received electricity }\end{array}$ & \\
\hline 1 & Kayar & 4 & 4 & \\
\hline 2 & Kayin & 67 & 55 & \\
\hline 3 & Chin & 4 & 1 & \multirow{3}{*}{$\begin{array}{l}63 \text { villages with Pilot } \\
\text { and Tr organizations }\end{array}$} \\
\hline 4 & Sagaing & 944 & 939 & \\
\hline 5 & Bago(West) & 652 & 532 & \\
\hline 6 & Bago(East) & 564 & 521 & \\
\hline 7 & Magway & 509 & 422 & \\
\hline 8 & Mon & 68 & 53 & \\
\hline 9 & Rakhine & 11 & 11 & \\
\hline 10 & Shan(South) & 159 & 88 & \\
\hline 11 & Shan(North) & 87 & 51 & \\
\hline 12 & Shan(East) & 9 & 2 & \\
\hline 13 & Ayeyarwaddy & 645 & 629 & \\
\hline \multirow[t]{2}{*}{14} & Nay Pyi Taw & 94 & 94 & $\begin{array}{l}2 \text { villages with the } \\
\text { permission of the } \\
\text { World Bank }\end{array}$ \\
\hline & $\begin{array}{l}\text { Sum of the } \\
\text { Electricity supply } \\
\text { company }\end{array}$ & 3817 & 3402 & \\
\hline 15 & $\begin{array}{l}\text { Yangon Electric } \\
\text { Power Corporation }\end{array}$ & 193 & 190 & \\
\hline 16 & $\begin{array}{l}\text { Mandalay Power } \\
\text { Supply Corporation }\end{array}$ & 384 & 379 & \\
\hline & Sum & 4394 & 3971 & \\
\hline
\end{tabular}




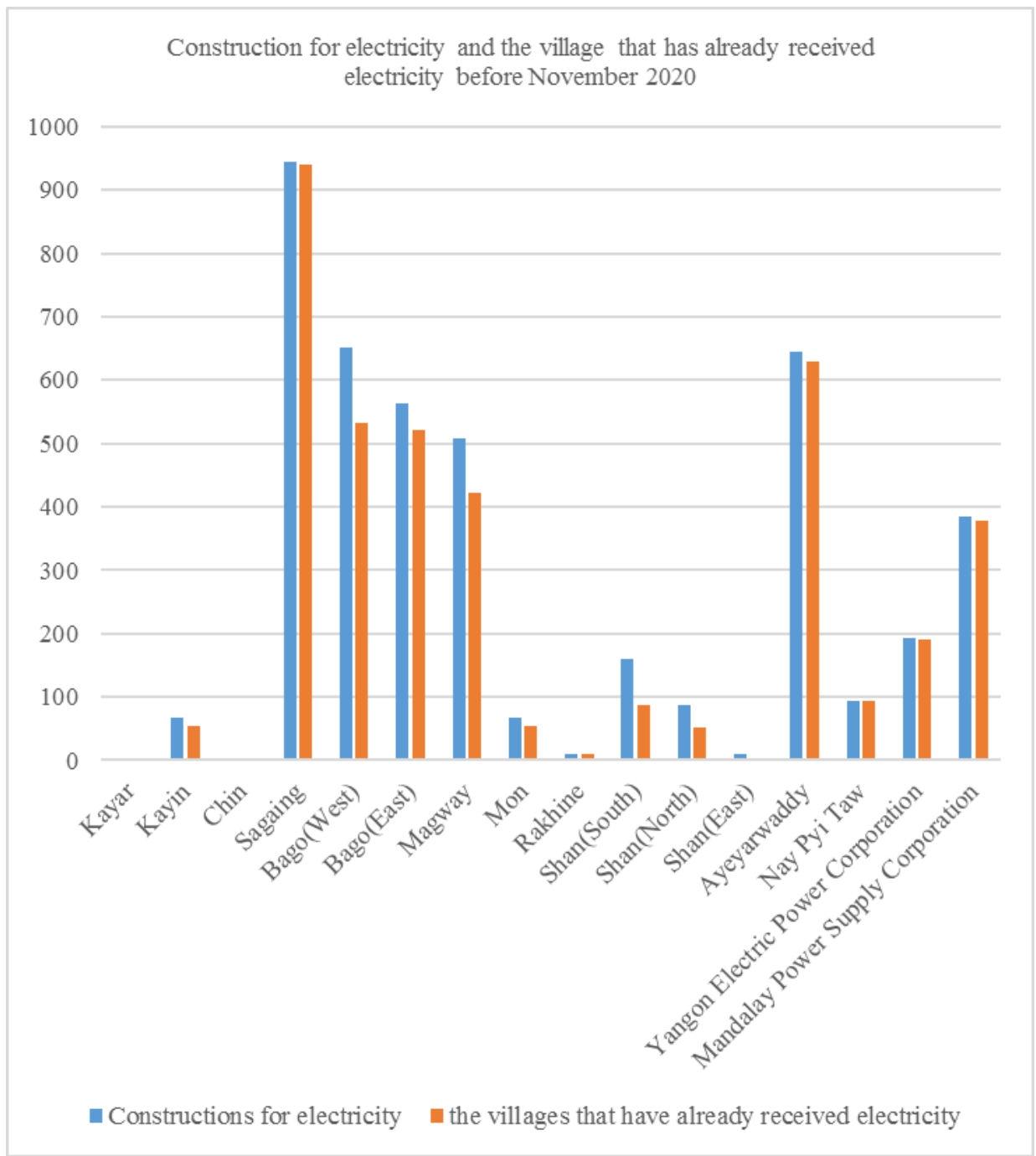

Fig. 2. According to the plan, the National Electricity Power Plan (NEPP), the Construction for electricity and the village that have already received electricity by November 2020 .

Table 2. Future plan National Electricity Plan (NPFE), build for electricity for the remaining villages that do not yet receive electricity.

Future plan of the National Electric Power Plan (NEPP)

\begin{tabular}{|l|l|}
\hline $\begin{array}{l}\text { the investment amount that will } \\
\text { be use }\end{array}$ & $\begin{array}{l}\text { The first step - After completing the construction for the village } \\
\text { on the territory of 3.22 km, we build further with approximately } \\
\$ 117.95 .\end{array}$ \\
\hline number of villages to build in & $\begin{array}{l}4700 \text { village and } 539674 \text { families on the territory of } 5 \mathrm{~km} \text { from } \\
\text { the Construction site }\end{array}$ \\
\hline Current state for second step & $\begin{array}{l}\text { The second step-has already invited a tender for the construction } \\
\text { of electricity on the territory of } 5 \mathrm{~km}\end{array}$ \\
\hline $\begin{array}{l}\text { Approval of the Ministry of } \\
\text { Electricity and Energy of } \\
\text { Myanmar }\end{array}$ & $\begin{array}{l}\text { After buying the necessary things to build for the villages, 59\% } \\
\text { have already come. }\end{array}$ \\
\hline approximate time will end & November 2021 \\
\hline
\end{tabular}




\subsection{Renewable Energy in Myanmar}

Renewable energy sources are sources based on constantly existing or periodically occurring energy flows in the environment. A typical example of such a source is solar radiation with a characteristic repetition period of 24 hours. Renewable energy is present in the environment in the form of energy that is not the result of purposeful human activity, and this is its distinctive feature.

Assessment of the requirements of agricultural electricity consumers, development of methods for assessing the categories of energy potential of RES resources in the context of socio-economic factors. Preliminary studies were conducted on rural consumption and the potential of Myanmar's renewable energy resources. By 2020, the prospective electricity consumption of rural and remote areas of Myanmar is projected to be 7,050 TW.h in the conditions of 2020 .

According to the geographical location of the country, the main rural population lives in areas where it is quite possible to use renewable energy resources. In the central plains region of Myanmar, solar energy is available all year round. Wind power installations can be implemented on the west coast and in the central area. In these areas, the average annual speed at the height of the weather vane is over $5 \mathrm{~m} / \mathrm{s}$. These studies and figures have shown that the country has huge resources of RES.

\section{Mathematical formulation}

The objective of this paper is to present, discuss, and apply the principles and techniques of the analytic hierarchy process (AHP) in the prioritization and selection of projects in a portfolio. AHP is one of the main mathematical models currently available to support the decision theory. 


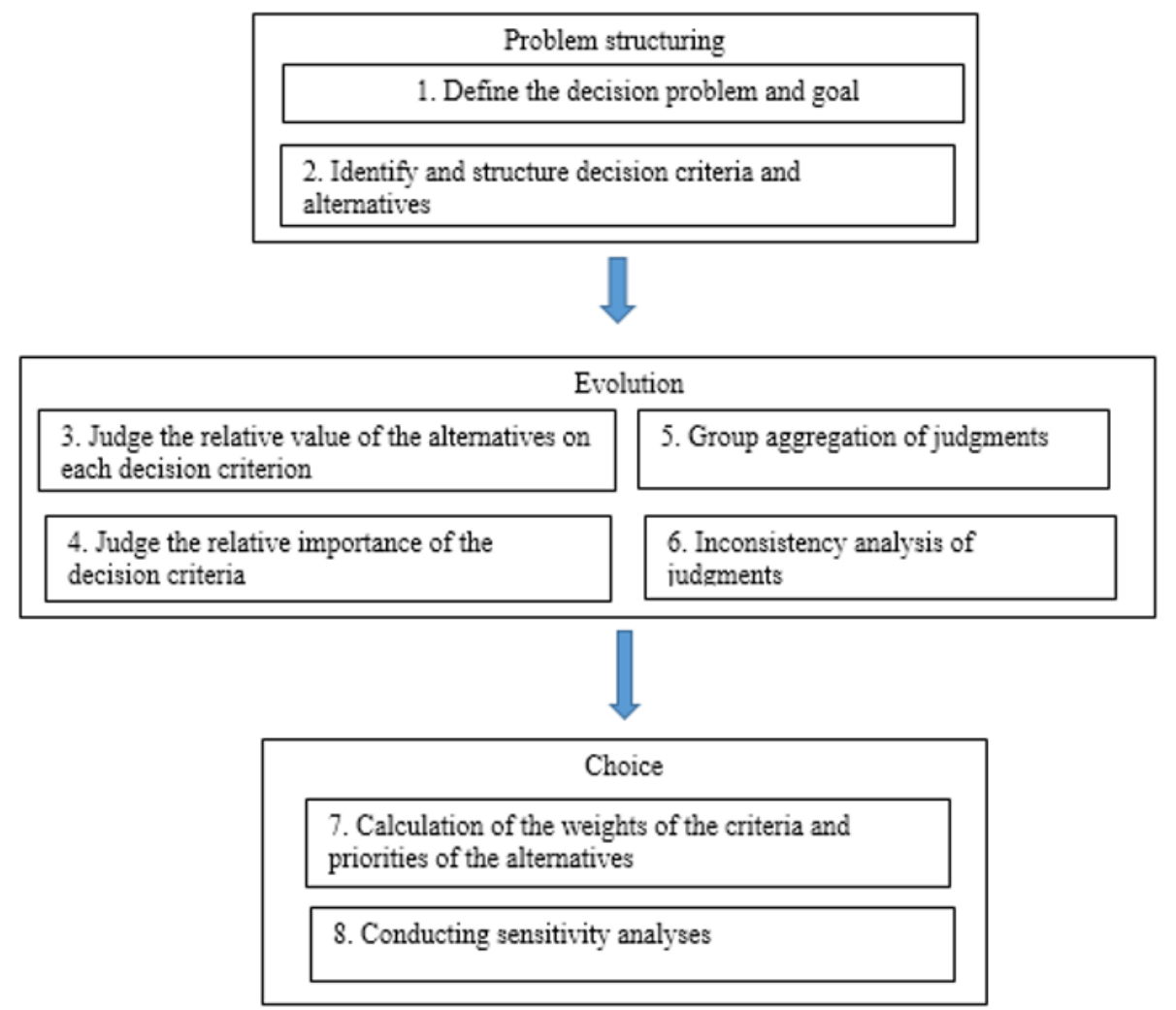

\section{Calculations to find the most optimal places for constructions of res in Myanmar}

\subsection{Myanmar solar energy resources}

The solar energy potential in Myanmar is 51,973. 8 TW.h per year, with an average of more than 5 hours of sunshine per day. Despite the fact that most of Myanmar's electricity is generated by hydroelectric power, the country has a rich technical potential for solar energy, which is the highest in the Greater Mekong sub region; however, in terms of installed capacity, Myanmar lags far behind Thailand and Vietnam. The country aims to produce $8 \%$ of its electricity from renewable energy sources - wind and solar-by 2021 and $12 \%$ by 2025 .

The calculations in this paper are based mainly on the data of "meteonorm" (2020). 


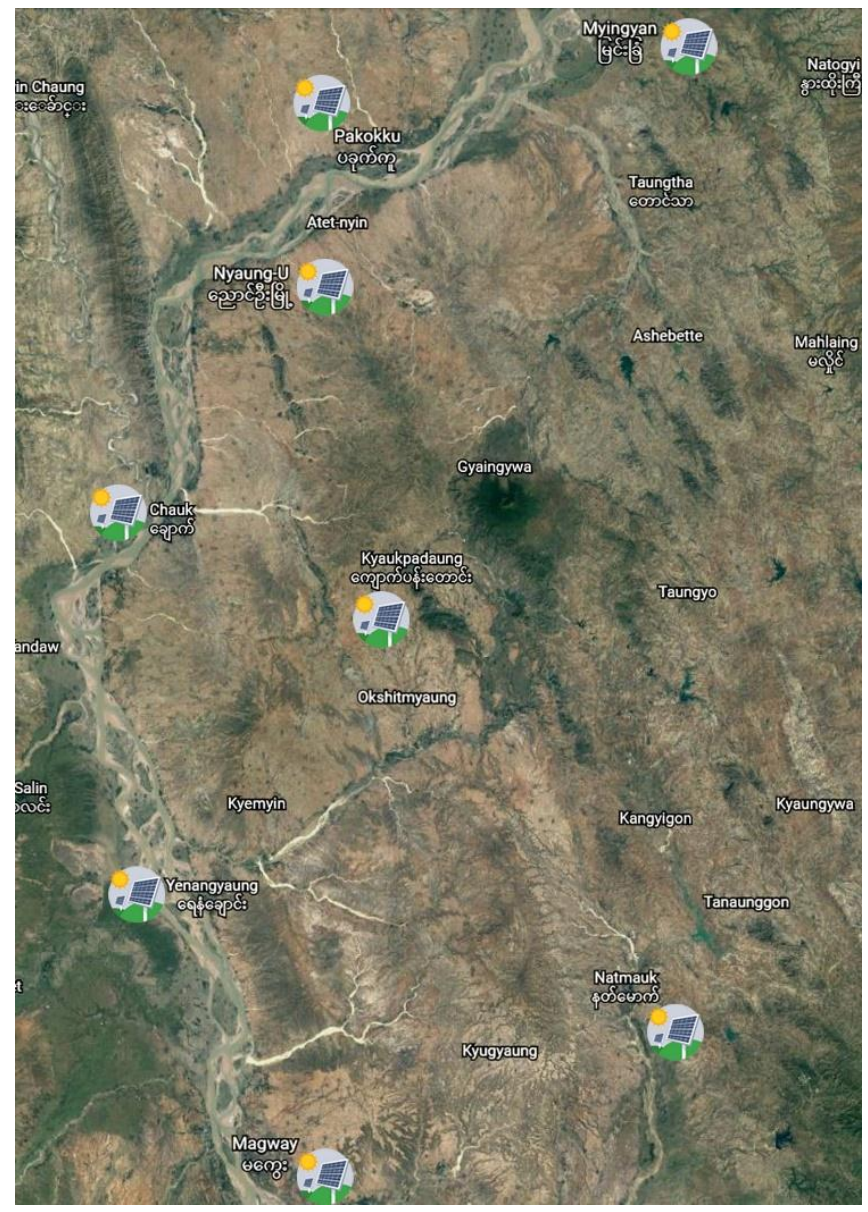

Fig. 3. Cities that choose to optimize for constructions of Solar Energy Stations.

Table 3. Average monthly solar radiation in major cities in Myanmar $\left(\mathrm{kWh} / \mathrm{m}^{2} /\right.$ month)

\begin{tabular}{|c|c|c|c|c|c|c|c|c|c|c|c|c|c|}
\hline No & $\begin{array}{l}\text { Location } \\
\text { /Cities }\end{array}$ & Jan & $\mathrm{Feb}$ & Mar & Apr & May & Jun & Jul & Aug & Sep & Oct & Nov & Dec \\
\hline 1. & Nay & & - & 10 & 0 & 179 & 48 & 134 & 138 & 148 & 139 & 137 & 140 \\
\hline 2. & & 150 & 148 & 179 & 189 & 151 & 120 & 117 & 106 & 138 & 136 & $\overline{120}$ & 137 \\
\hline 3. & $\mathrm{~N}$ & 140 & 145 & 165 & 180 & 180 & 145 & 122 & 138 & 142 & 128 & $\mid 130$ & 133 \\
\hline 4. & Myitkyina & 121 & 120.5 & 150 & 158 & 158 & 110 & 105 & 128 & 12 & 110 & 25 & 126 \\
\hline 5. & & 141 & 142 & 9 & 9 & 30 & 10 & 130 & 41 & 40 & 130 & 35 & 132 \\
\hline 6. & Tauı & 160 & 162 & 182 & 195 & 180 & 155 & 138 & 140 & 150 & 140 & 139 & 145 \\
\hline 7. & Koll & $\longdiv { 1 4 5 }$ & 40 & 165 & 185 & 190 & 150 & 138 & 145 & 140 & 139 & 142 & 140 \\
\hline 8. & & 101 & 50 & 1 & 5 & 157 & 19 & 109 & 110 & 140 & 140 & 130 & 135 \\
\hline 9. & aw & 15 & 145 & 173 & 185 & 0 & 119 & 115 & 95 & 144 & 140 & $\mid 128$ & 137 \\
\hline 10. & & $1^{1}$ & 140 & 179 & 188 & 13 & 112 & 125 & 101 & 145 & 140 & 130 & 145 \\
\hline $\mid 11$. & iviycin & 145 & 144 & 178 & 185 & | & 115 & 125 & 97 & נIJן & 0 & 133 & | \\
\hline
\end{tabular}


Table 4. Average monthly solar radiation in cities at the middle part of Myanmar ( $\left.\mathrm{kWh} / \mathrm{m}^{2} / \mathrm{month}\right)$.

\begin{tabular}{|c|c|c|c|c|c|c|c|c|c|c|c|c|c|}
\hline No & $\begin{array}{l}\text { Location } \\
\text { /Cities }\end{array}$ & Jan & $\mathrm{Feb}$ & Mar & Apr & May & Jun & Jul & Aug & Sep & Oct & Nov & Dec \\
\hline 1. & enan & 8 & 144 & $\mid 163$ & $\mid 172$ & 181 & 153 & 133 & 141 & 147 & $\mid 140$ & $\mid 130$ & 130 \\
\hline 2. & Citaun & 3 & $\mid 141$ & 159 & 70 & 180 & 53 & 137 & 138 & 140 & 138 & 25 & 124 \\
\hline 3. & Jya & 132 & 140 & 158 & $\mid 167$ & 180 & $|150|$ & $|140|$ & 136 & 136 & 135 & 123 & 122 \\
\hline 4. & Myi & 133 & 140 & $\mid 160$ & 170 & 179 & 150 & 145 & 145 & 145 & 132 & 125 & 125 \\
\hline 5. & Kyaukpadaung & 137 & 1 & 53 & $\mid 170$ & 182 & 155 & $\mid 143$ & 43 & 145 & 139 & $\mid 129$ & 127 \\
\hline 6. & $\mathrm{~N}$ & 143 & $\mid 145$ & 170 & $\mid 180$ & 183 & 157 & 144 & 145 & 150 & 141 & $\mid 130$ & 129 \\
\hline 7. & 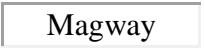 & 3 & 1 & $|170|$ & $|180|$ & 180 & $|150|$ & $|130|$ & 40 & $\mid 150$ & $\mid 142$ & $\mid 130$ & 133 \\
\hline 0. & Pakokku & 130 & 140 & 158 & 170 & 180 & 150 & 142 & 138 & 138 & 130 & 125 & 123 \\
\hline
\end{tabular}

Table 5. Highest Temperatures in major cities in Myanmar (C).

\begin{tabular}{|c|c|c|c|c|c|c|c|c|c|c|c|c|c|}
\hline No. & $\begin{array}{l}\text { Location } \\
\text { /Cities }\end{array}$ & Jan & Feb & Mar & Apr & May & Jun & Jul & Aug & Sep & Oct & Nov & Dec \\
\hline 1. & Nay Pyi Taw & 33.5 & 37 & 40 & 45 & 39 & 36 & 37 & 34.5 & 36 & 35.5 & 39 & 33.5 \\
\hline 2. & Yangon & 37 & 39 & 40 & 40 & 39 & 34 & 33 & 33 & 35 & 37 & 37.5 & 37.5 \\
\hline 3. & Mandalay & 34 & 38 & 42 & 42.5 & 42.5 & 38.5 & 39 & 37 & 37 & 37 & 36 & 34 \\
\hline 4. & Myitkyina & 25 & 28.5 & 31.5 & 34 & 35 & 34 & 32.5 & 32 & 33 & 32 & 29 & 26 \\
\hline 5. & Lashio & 25 & 29 & 33 & 34 & 34 & 33.5 & 33.5 & 34 & 34 & 32.5 & 29 & 27 \\
\hline 6. & Taunggyi & 25 & 28 & 30 & 32 & 33 & 30 & 30 & 28.5 & 28.5 & 28.5 & 27 & 24.5 \\
\hline 7. & Kalay & 29.5 & 35 & 39 & 38 & 37 & 35 & 35 & 34 & 35.5 & 37 & 34 & 32 \\
\hline 8. & Pago & 35.5 & 38 & 39 & 42 & 38 & 34.5 & 34.5 & 33.5 & 34 & 35.5 & 36 & 36.5 \\
\hline 9. & Mawlamyine & 35 & 37 & 39.5 & 41 & 38 & 35.5 & 35 & 33.5 & 34 & 34.5 & 37 & 34 \\
\hline 10. & Dawei & 35.5 & 38 & 39 & 40 & 37 & 35.5 & 37 & 33.5 & 34 & 34.5 & 35 & 35 \\
\hline 11. & Myeik & 35 & 36 & 36.5 & 37 & 36 & 34.5 & 33.5 & 33.5 & 33 & 34 & 35 & 35.5 \\
\hline
\end{tabular}

Table 6. Highest Temperatures in cities at the middle part of Myanmar (C).

\begin{tabular}{|c|c|c|c|c|c|c|c|c|c|c|c|c|c|}
\hline No. & $\begin{array}{l}\text { Location } \\
\text { /Cities }\end{array}$ & Jan & Feb & Mar & Apr & May & Jun & Jul & Aug & Sep & Oct & Nov & Dec \\
\hline 1. & Yenangyaung & 34.4 & 38 & 41 & 42.5 & 42 & 39.8 & 41 & 37.5 & 37.5 & 37 & 36.5 & 34.5 \\
\hline 2. & Chauk & 34.2 & 37 & 41.5 & 41.5 & 40 & 39 & 39.5 & 36.5 & 37 & 36 & 35.5 & 33 \\
\hline 3. & Nyaung-U & 34 & 37 & 42 & 42 & 41 & 38 & 38 & 37 & 36.5 & 37 & 35 & 34 \\
\hline 4. & Myingyan & 34 & 37 & 40.5 & 42 & 40.5 & 38 & 39 & 36.5 & 36.5 & 37 & 35.5 & 33 \\
\hline 5. & Kyaukpadaung & 32 & 36.5 & 39.5 & 41 & 39 & 37 & 38 & 35 & 36 & 35 & 35 & 31 \\
\hline 6. & Natmauk & 34 & 37 & 41 & 42 & 41 & 37 & 38 & 37 & 37 & 36.5 & 35 & 34 \\
\hline 7. & Magway & 33 & 37 & 41 & 42 & 41.5 & 37 & 38 & 36 & 37 & 36 & 35 & 33 \\
\hline
\end{tabular}




\begin{tabular}{|l|l|l|l|l|l|l|l|l|l|l|l|l|l|}
\hline 8. & Pakokku & 35 & 38 & 42 & 42 & 42.5 & 39 & 40 & 37 & 38 & 37 & 36.5 & 33
\end{tabular}

\subsubsection{Selection of the Site for the Construction of a RES Station by the "Analytical Hierarchy of Processes (AHP)" Method}

In Myanmar, there are some places where there is no national network. The report selects places where there is no national network, for which the calculation using the Analytical Hierarchy of Processes method will show where it is better to build RES stations.

To build a hierarchy, the factors that are important for decision-making are selected, including:

1. Resources - What energy is there in this place?

2. Environment, Condition-Myanmar is still in a civil war in some regions. In general, there is no national network in such places. The government is trying to build hydroelectric power stations in places where there is no national grid. If these factors (war and energy potential) are not taken into account, people, investments, time, etc. will be lost.

3. Transport-Especially in these regions, very dangerous transport. There are roads, but there is no safety. Sometimes there are bad roads.

4. Potential - Weather, landslide, floods, etc.

5. Cost-Prices often change for various reasons.

6. Specialists-Engineers, experienced workers, assistants, etc.

7. Security - Civil war on the border and in some other places. We need the help of the Army.

8. Insurance-Insurance companies will provide a deposit for any event, but this applies to all situations?

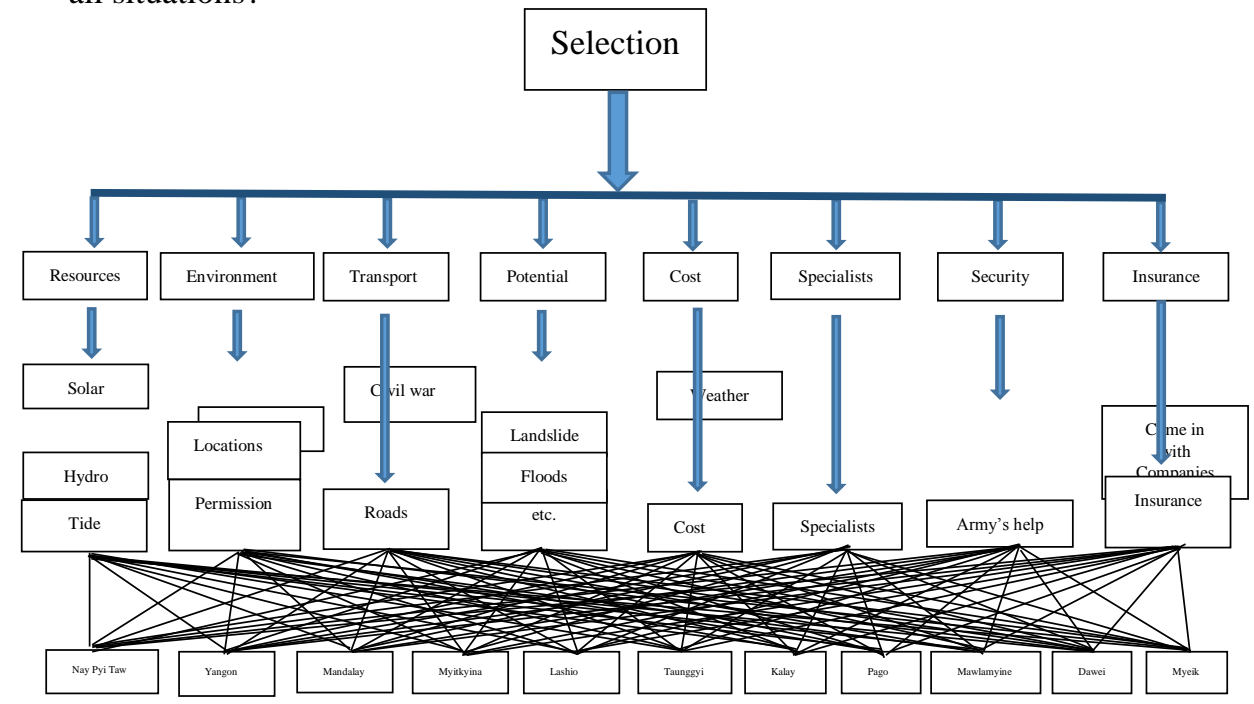

Diagram 1. Selection the most optimal Location for Solar Station using The "Analytical Hierarchy Process (AHP)" in Myanmar. 


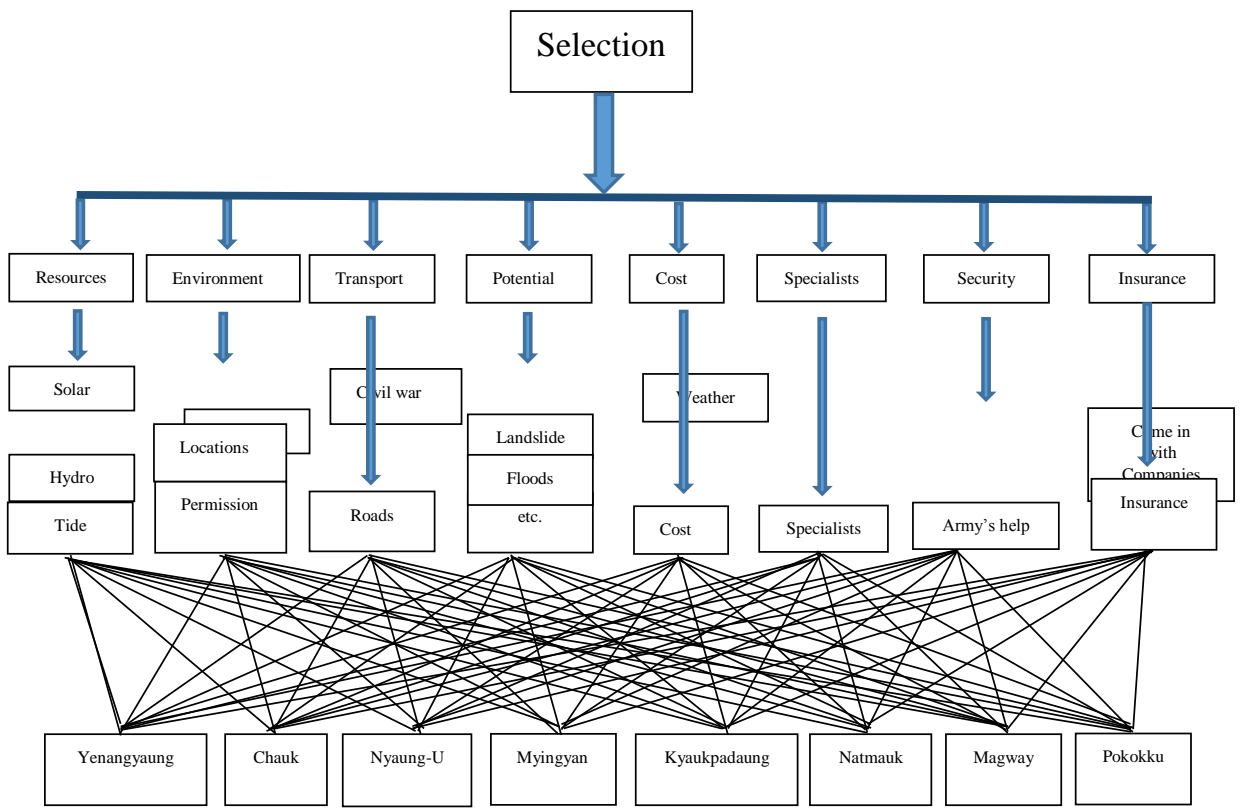

Diagram 2. Selection the most optimal Location for Solar Station using The "Analytical Hierarchy Process (AHP)" in the middle part of Myanmar.

Using pairwise comparisons, one can express the relative importance of one criterion over another. To do this, use the following procedure:

Let's set the values of the criteria in the form

1-equal, 2-moderate, 3-strong, 4-very strong, 5-extreme.

Using these criteria, we construct a matrix of paired comparisons.

\begin{tabular}{|c|c|c|c|c|c|c|c|c|}
\hline & Resources & Emironments & Transport & Fotential & cost & Specialists & securrty & inauranes: \\
\hline Rassurca: & $1 / 1$ & $2 / 1$ & $2 / 1$ & $3 / 1$ & $1 / 1$ & $2 / 1$ & $1 / 1$ & $2 / 1$ \\
\hline Emironment & $1 / 2$ & $2 / 2$ & $2 / 1$ & $2 / 1$ & $1 / 3$ & $1 / 3$ & $1 / 3$ & $1 / 3$ \\
\hline Transport & $1 / 2$ & $2 / 1$ & $3 / 3$ & $2 / 1$ & $1 / 3$ & $1 / 1$ & $1 / 3$ & $1 / 3$ \\
\hline Potential & $1 / 2$ & $1 / 2$ & $1 / 3$ & $4 / 6$ & $1 / 4$ & $1 / 3$ & $1 / 6$ & $1 / 6$ \\
\hline Cost & $1 / 1$ & $3 / 1$ & $3 / 1$ & $2 / 1$ & $5 / 5$ & $1 / 1$ & $1 / 1$ & $1 / 1$ \\
\hline Specialist: & $1 / 2$ & $2 / 1$ & $2 / 1$ & $2 / 1$ & $1 / 1$ & $6 / 6$ & $1 / 1$ & $1 / 1$ \\
\hline Securty & $1 / 1$ & $3 / 1$ & $2 / 1$ & $2 / 1$ & $1 / 2$ & $1 / 1$ & $7 / 7$ & $1 / 1$ \\
\hline Inouranse & $1 / 2$ & $2 / 1$ & $1 / 1$ & $2 / 1$ & $1 / 1$ & $1 / 1$ & $1 / 1$ & $8 / 3$ \\
\hline
\end{tabular}

Step 1. Squaring the matrix and converting fractions to decimals.

\begin{tabular}{|c|c|c|c|c|c|c|c|c|}
\hline & REsourses & Emironment & Transport & Fotential & $\cos$ & Specianses & securnty & Insurans: \\
\hline Resource: & 1 & $z$ & 2 & 3 & 1 & $z$ & 1 & $z$ \\
\hline Emironment & 0.5 & 1 & 2 & 2 & 0.3333 & 0.3333 & 0.3333 & 0.3333 \\
\hline Transport & 0.5 & $z$ & 1 & $z$ & 0.3333 & 1 & 0.3333 & 0.3333 \\
\hline Potential & 0.5 & 0.5 & 0.3333 & 1 & 0.25 & 0.3333 & 0.25 & 0.25 \\
\hline Cost & 1 & 3 & 3 & 2 & 1 & 1 & 1 & 1 \\
\hline Specialist: & 0.5 & $z$ & 2 & $z$ & 1 & 1 & 1 & 1 \\
\hline Security & 1 & 3 & 2 & $z$ & 0.5 & 1 & 1 & 1 \\
\hline Ineuranse & 0.5 & $z$ & 1 & 2 & 1 & 1 & 1 & 1 \\
\hline
\end{tabular}

Step 2. Calculate the first eigenvector of the matrix (up to four decimal places).

\begin{tabular}{|c|c|c|c|c|c|c|c|c|}
\hline & Resources & Emironment & Transport & Potential & $\cos$ & Speciallst: & secunty & Inourans: \\
\hline Resource: & 1 & $z$ & 2 & 3 & 1 & 2 & 1 & $z$ \\
\hline Emironment & 0.5 & 1 & 2 & 2 & 0.3333 & 0.3333 & 0.3333 & 0.3333 \\
\hline Transport & 0.5 & $z$ & 1 & 2 & 0.3333 & 1 & 0.3333 & 0.3333 \\
\hline Potential & 0.5 & 0.5 & 0.3333 & 1 & 0.25 & 0.3333 & 0.25 & 0.25 \\
\hline Cost & 1 & 3 & 3 & $z$ & 1 & 1 & 1 & 1 \\
\hline Specialist: & 0.5 & $z$ & $z$ & $z$ & 1 & 1 & 1 & 1 \\
\hline Securrty & 1 & 3 & $z$ & $z$ & 0.5 & 1 & 1 & 1 \\
\hline Inouranse & 0.5 & 2 & 1 & $z$ & 1 & 1 & 1 & \\
\hline
\end{tabular}


"Multiply with the same matrix"

\begin{tabular}{|c|c|c|c|c|c|c|c|c|}
\hline & Rosources: & Emironment & Transport & F otential & $\cos$ & Speciallats & securnty & insurans: \\
\hline Rassurea: & 1 & 2 & 2 & 3 & 1 & $z$ & 1 & 2 \\
\hline Emironment & 0.5 & 1 & 2 & 2 & 0.3333 & 0.3333 & 0.3333 & 0.3333 \\
\hline Transport & 0.5 & $z$ & 1 & $z$ & 0.3333 & 1 & 0.3333 & 0.3333 \\
\hline Potential & 0.5 & 0.5 & 0.3333 & 1 & 0.25 & 0.3333 & 0.25 & 0.25 \\
\hline Cont & 1 & 3 & 3 & 2 & 1 & 1 & 1 & 1 \\
\hline Spocialiss: & 0.5 & 2 & 2 & 2 & 1 & 1 & 1 & 1 \\
\hline security & 1 & 3 & 2 & 2 & 0.5 & 1 & 1 & 1 \\
\hline Inauranse & 0.5 & 2 & 1 & $z$ & 1 & 1 & 1 & 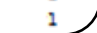 \\
\hline
\end{tabular}

And then, get the show results as shown in table 7 .

Table 7. Results by multiply with the same above matrix.

\begin{tabular}{|c|c|c|c|c|c|c|c|}
\hline 8.5 & 23.5 & 19.9999 & 26 & 8.5832 & 11.6665 & 9.0832 & 10.0832 \\
\hline 3.9999 & 10.333 & 8.333 & 12.1664 & 3.16645 & 5.3331 & 3.3331 & 3.8331 \\
\hline 4.33325 & 10.6664 & 10.6664 & 13.4998 & 3.83315 & 5.3331 & 3.9998 & 4.4998 \\
\hline 2.2083 & 5.3332 & 4.8332 & 6.3332 & 1.98603889 & 2.91655 & 2.111039 & 2.611039 \\
\hline 8 & 22 & 19.6666 & 25 & 6.9998 & 10.6665 & 7.4998 & 8.4998 \\
\hline 6.5 & 18 & 15.6666 & 19.5 & 5.8332 & 8.3332 & 6.3332 & 6.8332 \\
\hline 7 & 18.5 & 17.1666 & 22 & 6.1665 & 9.1665 & 6.6665 & 7.6665 \\
\hline 6 & 16 & 14.6666 & 17.5 & 5.4999 & 7.3332 & 5.9999 & 6.4999 \\
\hline
\end{tabular}

If add up all the columns from the table 7, will get a column matrix (Sum) as shown in Column 1.

Column 1. Results by adding all the columns from the table 7 .

\begin{tabular}{|r|}
\hline 117.416 \\
\hline 50.49805 \\
\hline 56.8317 \\
\hline 28.33257 \\
\hline 108.3325 \\
\hline 86.9994 \\
\hline 94.3326 \\
\hline 79.4995 \\
\hline
\end{tabular}

If add all the numbers of this column, the sum is 622.2423 .

If 622.2423 is multiply with the column column1, this result is as shown in column 2 .

Column 2. Results get by multiply with the column 1 and the sum of adding all number of column 1 .

\begin{tabular}{|c|c|c|}
\hline 0.1887 & Resources & 1 \\
\hline 0.0811 & Environment & 7 \\
\hline 0.0913 & Transport & 6 \\
\hline 0.0455 & Potential & 8 \\
\hline 0.1741 & Cost & 2 \\
\hline 0.1382 & Specialists & 4 \\
\hline 0.1517 & Security & 3 \\
\hline 0.128 & Insurance & 5 \\
\hline
\end{tabular}


This is the result-an eigenvector.

\begin{tabular}{|c|c|c|c|c|c|c|c|c|}
\hline & Rasoures: & Emironment & Tranaport & Potential & Cor & Spacialists & Security & Inaurance \\
\hline Nay Pyi Taw & & 1 & 1 & .03 & .1 & 2 & 2 & 27 \\
\hline Yangon & .08 & .2 & .2 & .06 & $z$ & .1 & $=1$ & $=1$ \\
\hline Mandalay & .09 & .1 & -1 & .06 & 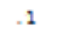 & .1 & .1 & 1 \\
\hline Myrthyina & .03 & .03 & .03 & .1 & .1 & .03 & .06 & .06 \\
\hline lashio & .06 & .06 & .06 & 2 & .03 & .06 & .03 & .03 \\
\hline Taungeril & .06 & .06 & .09 & .08 & .09 & .09 & .08 & 1 \\
\hline Kalay & .08 & .08 & .06 & .1 & .06 & .06 & .06 & .06 \\
\hline Pago & 1 & 1 & 1 & .08 & .1 & 1 & .09 & 1 \\
\hline Mawlamyine & $=1$ & .1 & -1 & .09 & .08 & .2 & .08 & .09 \\
\hline Dawsi & .1 & .09 & .08 & 1 & .08 & .08 & .1 & .08 \\
\hline Mysik & .1 & .08 & .08 & 1 & .06 & .08 & 1 & .08 \\
\hline
\end{tabular}

\begin{tabular}{|c|c|c|c|c|c|c|c|c|}
\hline & Razoures: & Emrironment & Transport & Potential & $\cos$ & Specialists & security & insurance \\
\hline Yenangyaung & 15 & .15 & 1 & .25 & .15 & 1 & .15 & 1 \\
\hline Chauk & $=1$ & -1 & .1 & .15 & .1 & .1 & 1 & 1 \\
\hline Nyaung - V & .1 & .15 & .15 & .1 & .17 & .17 & .15 & .13 \\
\hline Myingyan & $=1$ & .15 & .1 & -1 & .1 & .13 & .15 & .13 \\
\hline Kyaukpadaung & 1 & .15 & .15 & .1 & .13 & .13 & .1 & .17 \\
\hline Natmauk & .15 & 1 & 1 & 1 & 1 & 1 & 1 & 1 \\
\hline Magway & .15 & .1 & .25 & .15 & .25 & .17 & .15 & .17 \\
\hline Pakokiku & 15 & .1 & .15 & .15 & .1 & .1 & .1 & .1 \\
\hline
\end{tabular}

If multiply with the column 2 and the matrixes for the middle part of Myanmar and for the major cities of Myanmar, the results will show the most optimal locations.

The result for the major cities of Myanmar in table 8 .

Table 8. Results that show what city is the most optimal for the major cities of Myanmar.

\begin{tabular}{|c|c|r|c|}
\hline No. & Cities & Results & Rank \\
\hline 1 & Nay Pyi Taw & 0.03774 & 1 \\
\hline 2 & Yangon & 0.006488 & 10 \\
\hline 3 & Mandalay & 0.008217 & 9 \\
\hline 4 & Myitkyina & 0.001365 & 11 \\
\hline 5 & Lashio & 0.010446 & 7 \\
\hline 6 & Taunggyi & 0.008292 & 8 \\
\hline 7 & Kalay & 0.012136 & 6 \\
\hline 8 & Pago & 0.0128 & 5 \\
\hline 9 & Mawlamyine & 0.01354 & 4 \\
\hline 10 & Dawei & 0.013775 & 2 \\
\hline 11 & Myeik & 0.01401 & 3 \\
\hline
\end{tabular}

The results for the middle part of Myanmar in table 9.

Table 9. Results that show what city is the most optimal for the middle part of Myanmar.

\begin{tabular}{|c|c|c|c|}
\hline No. & Cities & Results & Rank \\
\hline 1 & Yenangyaung & 0.028 & 1 \\
\hline 2 & Chauk & 0.008 & 7 \\
\hline 3 & Nyaung-U & 0.009 & 6 \\
\hline 4 & Myingyan & 0.004 & 8 \\
\hline 5 & Kyaukpadaung & 0.017 & 5 \\
\hline 6 & Natmauk & 0.02 & 3 \\
\hline 7 & Magway & 0.022 & 2 \\
\hline 8 & Pakokku & 0.019 & 4 \\
\hline
\end{tabular}

The result shown is obtained. 
Sum -1 . If the sum of places $=1$, the ranking is correct. Now a little more matrix algebra gives the solution to choose a place.

The result for the major cities of Myanmar is $(0.03774)$ - the best place to build a solar station.

The result for the middle part of Myanmar is Yenangyaung (0.028) - the best place to build a solar station.

\subsection{Myanmar wind energy resources}

Myanmar's Department of Renewable Energy and Hydroelectric Power gives priority to the development of solar and wind energy. The Rakhine, Tanintharyi and Irrawaddy regions have been identified as areas with strong wind energy potential, but the potential for solar energy is higher than that of wind energy in Myanmar. Myanmar is building its first wind farm in Chaung Thar, Irrawaddy region, as part of a $30 \mathrm{MW}$ wind power project it is implementing jointly with China's Three Gorges Corporation.

The selection of a site for a large offshore wind farm operating in the unified energy system should be carried out in accordance with the following criteria: wind intensity; depth of the seabed; availability of transport infrastructure; possibility of technical connection of the projected wind farm to the power system; distance from the site to the substation ; absence of environmental and other restrictions (for example, economic, military or environmental activities should not be carried out on the proposed sites). The choice of the available area for the placement of offshore wind farms was made taking into account the absence of environmental and other restrictions. It was also revealed that almost the entire available area for offshore wind farms is promising in terms of wind intensity, since the average long-term wind speeds over the entire allocated territory at an altitude of 100 meters are higher than $6.7 \mathrm{~m} / \mathrm{s}$. Further selection of offshore wind farm sites on the previously selected available territory was made according to the criterion of the possibility of technical connection of the projected offshore wind farm to the power system.

An analysis of the location of existing $230 \mathrm{~kW}$ substations on the west coast of Myanmar allowed us to identify eight promising sites for offshore WES on the previously planned territory for offshore WES. Moreover, the sites were considered taking into account the depth of the sea up to $30 \mathrm{~m}$, i.e. the possibility of placing wind power plants (wind turbines) of the proposed offshore WES on a fixed basis, and technical connection to the Program Complex $230 \mathrm{~kW}$. The analysis of the possibility of technical connection of an offshore WES at the corresponding site to the nearest Program Complex allowed us to identify the power range of the projected offshore WES: from 30 MW (WES sites: 1, 3, 5, 6) to $80 \mathrm{MW}$ (WES site 2). Information on Program Complex and offshore wind farm sites are presented in Table 10: the average distance from the WES to the shore $\mathrm{r}$; the range of sea depth changes at the WES; the average distance from the WES to the nearest substations $\mathrm{r} 2$; the power of transformers (PT) of substations in MVA; the PT load of substation's data in \%; free capacity for the technical connection of offshore WES in MVA Sfree; approximate area available for the placement of WES Favailable.

And Figure 4. Shows the location of substations and the selected sites located on the west coast of Myanmar and Data on electrical substations and offshore wind farm sites in table $10[10]$. 


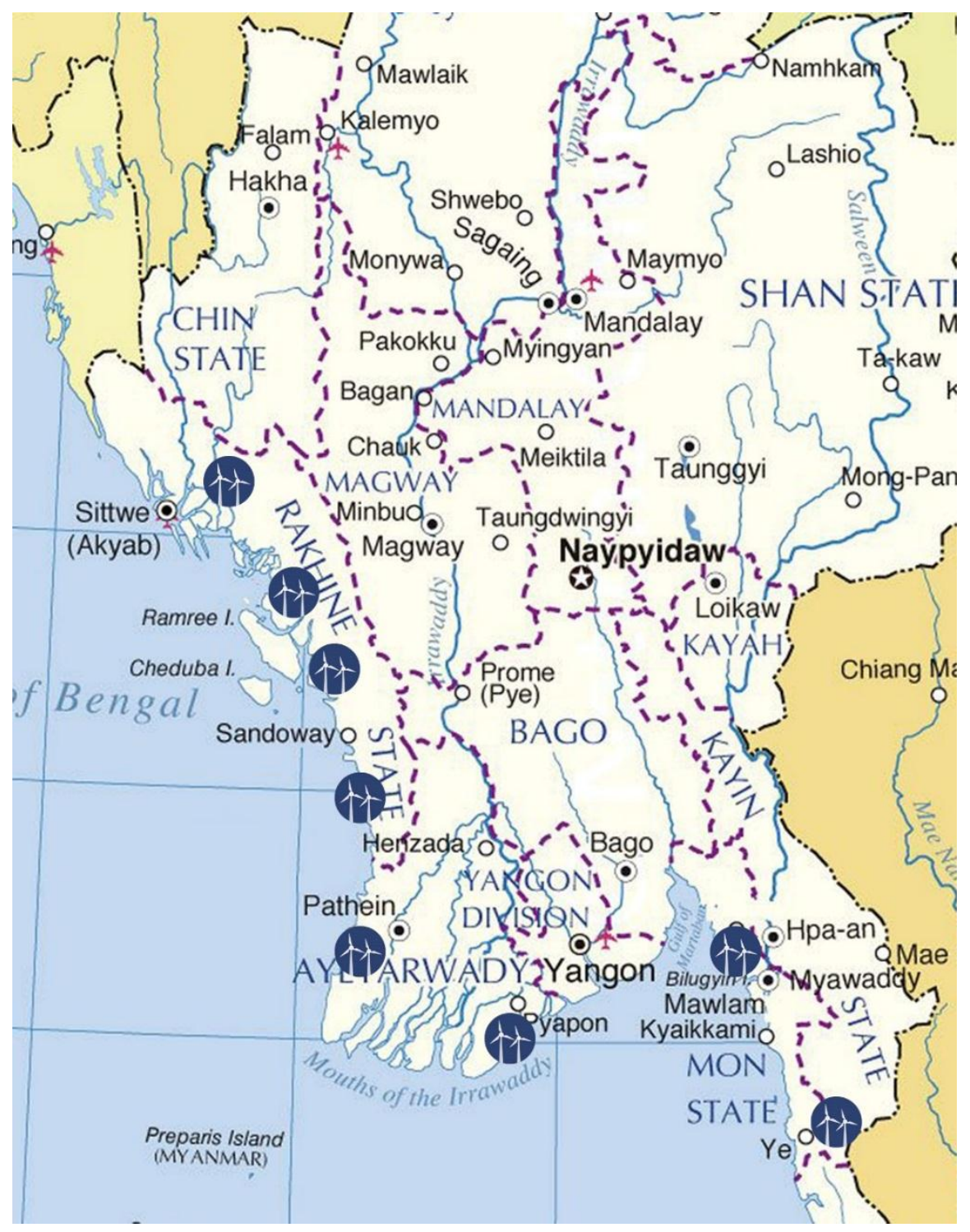

Fig. 4. Locations of promising sites for offshore wind farms and substations of the Myanmar energy system.

Table 10. Data on electrical substations and offshore wind farm sites.

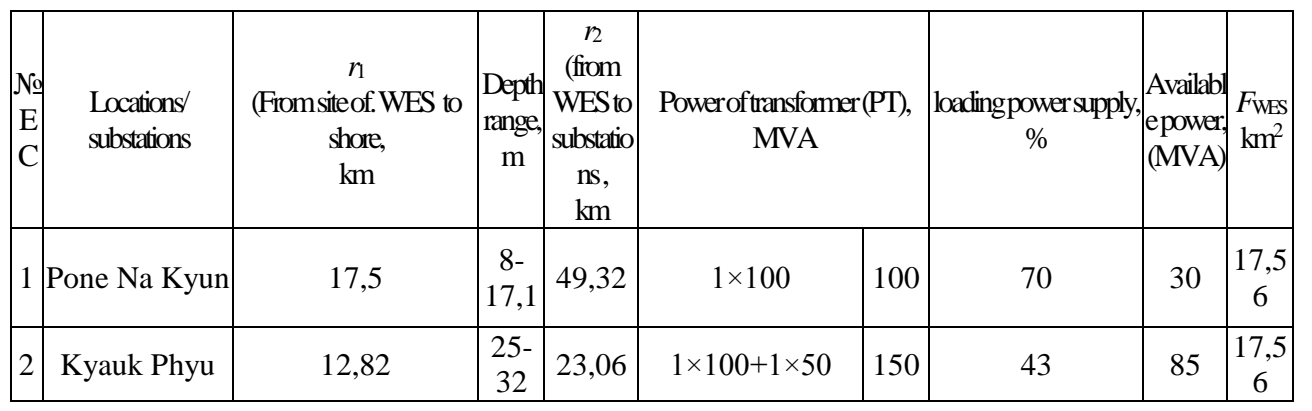




\begin{tabular}{|c|c|c|r|c|c|c|c|c|c|}
\hline 3 & Taung Kote & 32,8 & $\begin{array}{r}20- \\
30\end{array}$ & 77,8 & $1 \times 100$ & 100 & 64 & 36 & $\begin{array}{c}17,5 \\
6\end{array}$ \\
\hline 4 & A Toke & $5,0-9,0$ & $\begin{array}{c}6- \\
43,0\end{array}$ & 74 & $1 \times 100$ & 100 & 55 & 45 & $\begin{array}{c}17,5 \\
6\end{array}$ \\
\hline 5 & Pathein 1 & $11-16,0$ & $\begin{array}{r}17- \\
36,0\end{array}$ & 116 & $2 \times 50$ & 100 & 65 & 35 & $\begin{array}{c}17,5 \\
6\end{array}$ \\
\hline 6 & Pathein 2 & $20,0-30$ & $\begin{array}{c}13- \\
27,0 \\
0\end{array}$ & 165 & $2 \times 50$ & 100 & 65 & 35 & $\begin{array}{c}17,5 \\
6\end{array}$ \\
\hline 7 & $\begin{array}{c}\text { Mawlamyine } \\
1\end{array}$ & $16-20,0$ & $\begin{array}{c}9- \\
12,0\end{array}$ & 52 & $3 \times 50$ & 150 & 60 & 60 & $\begin{array}{c}17,5 \\
6\end{array}$ \\
\hline 8 & $\begin{array}{c}\text { Mawlamyine } \\
2\end{array}$ & $26-30$ & 22 & 130 & $3 \times 50$ & 150 & 60 & 60 & $\begin{array}{c}17,5 \\
6\end{array}$ \\
\hline
\end{tabular}

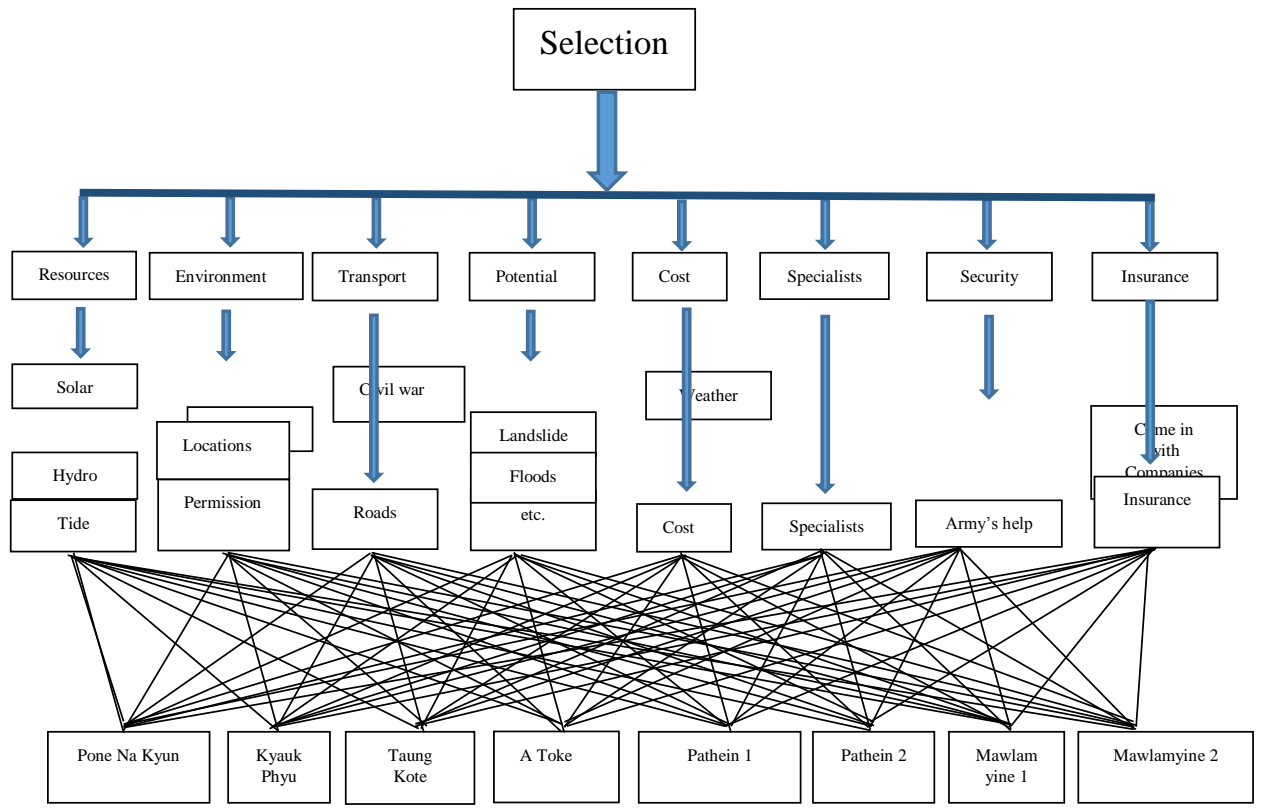

Diagram 3. Selection the most optimal Location for Wind Station using The "Analytical Hierarchy Process (AHP)" in offshore of Myanmar.

Using pairwise comparisons, one can express the relative importance of one criterion over another. To do this, use the following procedure:

Let's set the values of the criteria in the form

1-equal, 2-moderate, 3-strong, 4-very strong, 5-extreme.

Using these criteria, we construct a matrix of paired comparisons.

\begin{tabular}{|c|c|c|c|c|c|c|c|c|}
\hline & Rewoures: & Emironments & Tranaport: & Potsntial & cost & Specialists & securnty & Inourance \\
\hline Rassurca: & $1 / 1$ & $2 / 1$ & $2 / 1$ & $3 / 1$ & $1 / 1$ & $2 / 1$ & $1 / 1$ & $2 / 17$ \\
\hline Emironment & $1 / 2$ & $2 / 2$ & $2 / 1$ & $2 / 1$ & $1 / 3$ & $1 / 3$ & $1 / 3$ & $1 / 3$ \\
\hline Transport & $1 / 2$ & $2 / 1$ & $3 / 3$ & $2 / 1$ & $1 / 3$ & $1 / 1$ & $1 / 3$ & $1 / 3$ \\
\hline Potential & $1 / 2$ & $1 / 2$ & $1 / 3$ & $4 \sqrt{6}$ & $1 / 4$ & $1 / 3$ & $1 / 6$ & $1 / 4$ \\
\hline Cont & $1 / 1$ & $3 / 1$ & $3 / 1$ & $2 / 1$ & $5 / 5$ & $1 / 1$ & $1 / 1$ & $1 / 1$ \\
\hline Specialias: & $1 / 2$ & $2 / 1$ & $2 / 1$ & $2 / 1$ & $1 / 1$ & $6 / 6$ & $1 / 1$ & $1 / 1$ \\
\hline Securty & $1 / 1$ & $3 / 1$ & $2 / 1$ & $2 / 1$ & $1 / 2$ & $1 / 1$ & $7 / 7$ & $1 / 1$ \\
\hline Inauranse & $1 / 2$ & $2 / 1$ & $1 / 1$ & $2 / 1$ & $1 / 1$ & $1 / 1$ & $1 / 1$ & $3 / 3$ \\
\hline
\end{tabular}

Step 1. Squaring the matrix and converting fractions to decimals. 


\begin{tabular}{|c|c|c|c|c|c|c|c|c|}
\hline & Ressures & Emironmant & Transport & Potsmtial & $\cos$ & specianses & securnty & Inourance \\
\hline Resoures: & 1 & $z$ & $z$ & 3 & 1 & 2 & 1 & 2 \\
\hline Emironment & 0.5 & 1 & 2 & 2 & 0.3333 & 0.3333 & 0.3333 & 0.3333 \\
\hline Transport & 0.5 & $z$ & 1 & $z$ & 0.3333 & 1 & 0.3333 & 0.3333 \\
\hline Potential & 0.5 & 0.5 & 0.3333 & 1 & 0.25 & 0.3333 & 0.25 & 0.25 \\
\hline $\cos$ & 1 & 3 & 3 & 2 & 1 & 1 & 1 & 1 \\
\hline Specialists & 0.5 & $z$ & $z$ & $z$ & 1 & 1 & 1 & 1 \\
\hline Socurny & 1 & 3 & $z$ & $z$ & 0.5 & 1 & 1 & 1 \\
\hline Inauranse & 0.5 & 2 & 1 & 2 & 1 & 1 & 1 & 1 \\
\hline
\end{tabular}

Step 2. Calculate the first eigenvector of the matrix (up to four decimal places).

\begin{tabular}{|c|c|c|c|c|c|c|c|c|}
\hline & Resource: & Emironmsnt & Transport & Potential & $\cos$ & Specialists & security & inourane: \\
\hline Rasource: & $\Gamma_{1}$ & $z$ & 2 & 3 & 1 & $z$ & 1 & 27 \\
\hline Emironment & 0.5 & 1 & 2 & 2 & 0.3333 & 0.3333 & 0.3333 & 0.3333 \\
\hline Transport & 0.5 & $z$ & 1 & 2 & 0.3333 & 1 & 0.3333 & 0.3333 \\
\hline Potential & 0.5 & 0.5 & 0.3333 & 1 & 0.25 & 0.3333 & 0.25 & 0.25 \\
\hline Cost & 1 & 3 & 3 & 2 & 1 & 1 & 1 & 1 \\
\hline Specialists & 0.5 & 2 & 2 & $z$ & 1 & 1 & 1 & 1 \\
\hline Sacurity & 1 & 3 & 2 & 2 & 0.5 & 1 & 1 & 1 \\
\hline Inouranse & 0.5 & $z$ & 1 & $z$ & 1 & 1 & 1 & , \\
\hline
\end{tabular}

"Multiply with the same matrix"

\begin{tabular}{|c|c|c|c|c|c|c|c|c|}
\hline & Resources: & Emironment & Transport & Potsntial & $\cos$ & Specianses & secunty & insurance \\
\hline Rassurce: & 1 & $z$ & 2 & 3 & 1 & $z$ & 1 & 27 \\
\hline Emironment & 0.5 & 1 & 2 & 2 & 0.3333 & 0.3333 & 0.3333 & 0.3333 \\
\hline Transport & 0.5 & $z$ & 1 & $z$ & 0.3333 & 1 & 0.3333 & 0.3333 \\
\hline Potential & 0.5 & 0.5 & 0.3333 & 1 & 0.25 & 0.3333 & 0.25 & 0.25 \\
\hline Cost & 1 & 3 & 3 & $z$ & 1 & 1 & 1 & 1 \\
\hline Specialists & 0.5 & $z$ & $z$ & $z$ & 1 & 1 & 1 & 1 \\
\hline Security & 1 & 3 & 2 & $z$ & 0.5 & 1 & 1 & 1 \\
\hline Insuranse & 0.5 & 2 & 1 & $z$ & 1 & 1 & 1 & 1 \\
\hline
\end{tabular}

And then, get the show results as shown in table 11 .

Table 11. Results by multiply with the same above matrix.

\begin{tabular}{|c|c|c|c|c|c|c|c|}
\hline 8.5 & 23.5 & 19.9999 & 26 & 8.5832 & 11.6665 & 9.0832 & 10.0832 \\
\hline 3.9999 & 10.333 & 8.333 & 12.1664 & 3.16645 & 5.3331 & 3.3331 & 3.8331 \\
\hline 4.33325 & 10.6664 & 10.6664 & 13.4998 & 3.83315 & 5.3331 & 3.9998 & 4.4998 \\
\hline 2.2083 & 5.3332 & 4.8332 & 6.3332 & 1.98603889 & 2.91655 & 2.111039 & 2.611039 \\
\hline 8 & 22 & 19.6666 & 25 & 6.9998 & 10.6665 & 7.4998 & 8.4998 \\
\hline 6.5 & 18 & 15.6666 & 19.5 & 5.8332 & 8.3332 & 6.3332 & 6.8332 \\
\hline 7 & 18.5 & 17.1666 & 22 & 6.1665 & 9.1665 & 6.6665 & 7.6665 \\
\hline 6 & 16 & 14.6666 & 17.5 & 5.4999 & 7.3332 & 5.9999 & 6.4999 \\
\hline
\end{tabular}

If add up all the columns from the table 11, will get a column matrix (Sum) as shown in Column 3.

Column 3. Results by adding all the columns from the table 11 .

\begin{tabular}{|r|}
\hline 117.416 \\
\hline 50.49805 \\
\hline 56.8317 \\
\hline 28.33257 \\
\hline 108.3325 \\
\hline 86.9994 \\
\hline 94.3326 \\
\hline 79.4995 \\
\hline
\end{tabular}

If add all the numbers of this column, the sum is 622.2423 . 
If 622.2423 is multiply with the column column1, this result is as shown in column 4 .

Column 4. Results get by multiply with the column 3 and the sum of adding all number of column 3.

\begin{tabular}{|c|c|c|}
\hline 0.1887 & Resources & 1 \\
\hline 0.0811 & Environment & 7 \\
\hline 0.0913 & Transport & 6 \\
\hline 0.0455 & Potential & 8 \\
\hline 0.1741 & Cost & 2 \\
\hline 0.1382 & Specialists & 4 \\
\hline 0.1517 & Security & 3 \\
\hline 0.128 & Insurance & 5 \\
\hline
\end{tabular}

This is the result-an eigenvector.

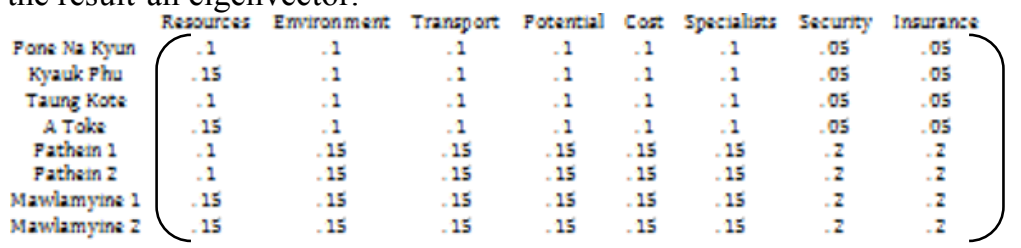

If multiply with the column 4 and the matrixes for the offshore part of Myanmar, the results will show the most optimal locations.

The results for the offshore part of Myanmar in table 12.

Table 12. Results that show what city is the most optimal for the offshore part of Myanmar.

\begin{tabular}{|c|c|c|c|}
\hline No. & Cities & Results & Rank \\
\hline 1 & Pone Na Kyun & 0.01887 & 3 \\
\hline 2 & Kyauk Phu & 0.012165 & 6 \\
\hline 3 & Taung Kote & 0.00913 & 7 \\
\hline 4 & A Toke & 0.006825 & 8 \\
\hline 5 & Pathein 1 & 0.01741 & 4 \\
\hline 6 & Pathein 2 & 0.01382 & 5 \\
\hline 7 & Mawlamyine 1 & 0.022755 & 1 \\
\hline 8 & Mawlamyine 2 & 0.0192 & 2 \\
\hline
\end{tabular}

The result shown is obtained.

Sum -1 . If the sum of places $=1$, the ranking is correct. Now a little more matrix algebra gives the solution to choose a place.

The result for the offshore part of Myanmar is Mawlamyine $1(0.022755)$ - the best place to build a wind station.

\section{Conclusions}

In this paper, calculating parameters and optimizing the best place to construct Renewable Energy Stations. In Myanmar there are more seriously to build energy stations because of political reasons. There are many reasons to be considered in Myanmar. These reasons are changed as the criteria to build diagram to be optimized the most suitable place from many different places (anyway locations where can get renewable energy resources).

1. Information of the energy resources in Myanmar. 
2. Solar and wind energy resources of Myanmar and selecting locations.

3. Building tree diagram to select the most optimal place from some places by using Analytic Hierarchy Process (AHP) method.

4. Calculations to find the most optimal places for constructions of RES in Myanmar.

5. Getting the most optimal places for constructions of RES in Myanmar.

\section{References}

1. http://en.wikipedia.org/wiki/Burma

2. http://www.asianinfo.org/asianinfo/myanmar/pro-geography.htm

3. R.Lee Hayden. An annotated bibliography of Burma's geology, geography and earth science, September 2008.

4. http://www.myanmar-embassy-tokyo.net/about.htm

5. http://www.weatheronline.co.uk/reports/climate/Myanmar.htm

6. https://ru.qaz.wiki/wiki/Energy_in_Myanmar

7. https://wikichi.ru/wiki/History_of_Myanmar

8. http://myelectro.com.ua/222-manyama-postroit-41-elektrostantsiyu-za-15-let

9. Ministerstvo elektroenergii i energetiki M'yanmy

10. Htet Myat Htoon, Deryugina G. V., Moscow Power Engineering Institute, Feasibility study of an offshore wind farm that is part of the Myanmar Power Grid, 2020. 